\title{
Tribological Behavior of 1Cr18Ni9Ti Steel under Hydrogen Peroxide Solution against Different Ceramic Counterparts
}

\author{
Yu Yuan', Wang Jun'， Li Jinshan'， Kou Hongchao'， Duan Haitao²， Li Jian², \\ Liu Weimin ${ }^{3}$
}

${ }^{1}$ State Key Laboratory of Solidification Processing, Northwestern Polytechnical University, Xi'an 710072, China; ${ }^{2}$ Wuhan Research Institute of Materials Protection, Wuhan 430000, China; ${ }^{3}$ State Key Laboratory of Solid Lubrication, Lanzhou Institute of Chemical Physics, Chinese Academy of Sciences, Lanzhou 730000, China

\begin{abstract}
We investigated the effect of counterface of $\mathrm{ZrO}_{2}, \mathrm{Si}_{3} \mathrm{~N}_{4}$ and $\mathrm{SiC}$ ceramics on the tribological behavior of $1 \mathrm{Cr} 18 \mathrm{Ni} 9 \mathrm{Ti}$ steel in $90 \%$ hydrogen peroxide solution. The results show that the tribological properties of $1 \mathrm{Cr} 18 \mathrm{Ni}$ Ti steel are strongly dependent on the counterfaces. The adhesion behavior affects the tribocouple of $1 \mathrm{Cr} 18 \mathrm{Ni} 9 \mathrm{Ti} / \mathrm{ZrO}_{2}$, leading to a high coefficient of friction (COF) fluctuating from 0.17 to 0.27 and the highest wear loss of $1 \mathrm{Cr} 18 \mathrm{Ni} 9 \mathrm{Ti}$ steel. The oxidation and hydrolysis protect the worn surface of $1 \mathrm{Cr} 18 \mathrm{Ni} 9 \mathrm{Ti} / \mathrm{SiC}$, inducing a low $\mathrm{COF} 0.035$ and the lowest wear loss of $1 \mathrm{Cr} 18 \mathrm{Ni}$ Ti steel. Both the adhesion behavior and the reactions play important roles in the wear behavior of $1 \mathrm{Cr} 18 \mathrm{Ni} 9 \mathrm{Ti} / \mathrm{Si}_{3} \mathrm{~N}_{4}$, leading to a complex $\mathrm{COF}$ and intermediate wear loss of $1 \mathrm{Cr} 18 \mathrm{Ni} 9 \mathrm{Ti}$ steel. As for the counterparts, $\mathrm{ZrO}_{2}$ ceramic shows the most severe wear, $\mathrm{SiC}$ ceramic shows relatively low wear volume, and $\mathrm{Si}_{3} \mathrm{~N}_{4}$ ceramic presents the lowest wear volume.
\end{abstract}

Key words: hydrogen peroxide; tribological property; counterpart; tribochemistry; adhesion

High concentration hydrogen peroxide (HCP), including hydrogen peroxide concentrations ranging from $70 \%$ to $98 \%$ is receiving renewed interest as a monopropellant and the oxidizer for bipropellant systems ${ }^{[1]}$. However, the strong oxidizing property of $\mathrm{H}_{2} \mathrm{O}_{2}$ determines the incompatibility of most alloys and excessive wear of tribo-pairs ${ }^{[2,3]}$. Pure $\mathrm{Al}$ and $1 \mathrm{Cr} 18 \mathrm{Ni} 9 \mathrm{Ti}$ stainless steel are the rarely compatible materials of $\mathrm{H}_{2} \mathrm{O}_{2}{ }^{[4]}$. Compared with the soft pure $\mathrm{Al}, 1 \mathrm{Cr} 18 \mathrm{Ni9Ti}$ stainless steel with good mechanical strength, processing property and corrosion resistance, is potential to preserve nice wear-resistance and be moving parts in $\mathrm{H}_{2} \mathrm{O}_{2}$ solution ${ }^{[5,6]}$. Wear, as a complex phenomenon during the surface interaction, is affected by the structures of both materials in the tribo-pair ${ }^{[7,8]}$. Studying the wear mechanism of different materials coupled with $1 \mathrm{Cr} 18 \mathrm{Ni}$ Ti stainless to design the tribo-pairs with nice tribological property in HCP, is important for the new propulsion systems.
C. Q. Yuan et al found that the $1 \mathrm{Cr} 18 \mathrm{Ni}$ Ti steel/ $/ \mathrm{Si}_{3} \mathrm{~N}_{4}$ ceramic rubbing pair could preserve nice wear-resistance ${ }^{[3]}$. In addition, it was reported that $\mathrm{SiC}$ ceramic also could preserve low $\mathrm{COF}$ (coefficient of friction) and wear loss in $\mathrm{HCP}{ }^{[9]}$. With nice compatibility in $\mathrm{H}_{2} \mathrm{O}_{2}$ solution ${ }^{[5]}$ and good wear-resistance ${ }^{[10,11]}, \mathrm{SiC}$ and $\mathrm{Si}_{3} \mathrm{~N}_{4}$ ceramics are potential to be the good counterpart of $1 \mathrm{Cr} 18 \mathrm{Ni}$ Ti steel in the HCP propellant systems. However, very few papers focused on the difference between the wear mechanism of $\mathrm{Si}_{3} \mathrm{~N}_{4}$ and $\mathrm{SiC}$ ceramics in HCP.

Aiming at understanding the aforementioned points, we investigated the tribological properties of $1 \mathrm{Cr} 18 \mathrm{Ni} 9 \mathrm{Ti}$ stainless steel sliding against $\mathrm{ZrO}_{2}, \mathrm{Si}_{3} \mathrm{~N}_{4}$ and $\mathrm{SiC}$ ceramics in $90 \%$ hydrogen peroxide solution. The wear mechanisms were studied by the worn surfaces of both $1 \mathrm{Cr} 18 \mathrm{Ni}$ Ti stainless and corresponding ceramics.

Received date: March 15, 2015

Foundation item: National Natural Science Foundation of China (51271151); the Program of Introducing Talents of Discipline to Universities (B08040)

Corresponding author: Wang Jun, Ph. D., Associate Professor, State Key Laboratory of Solidification Processing, Northwestern Polytechnical University, Xi'an 710072, P. R. China, Tel: 0086-29-88491764, E-mail: nwpuwj@nwpu.edu.cn 


\section{Experiment}

The XRD pattern and chemical composition (wt\%) of 1Cr18Ni9Ti steel are presented in Fig.1. The tribological tests were conducted on a SST-ST pin-on-disc tribometer (Wazau Germany) in $90 \%$ hydrogen peroxide solution at average room temperature of $(298 \pm 2) \mathrm{K}$. In order to insure required face-to-face mating and perpendicularity between the pin and disc, the ingots were fabricated into pin specimens of $\Phi 8$ $\mathrm{mm} \times 15 \mathrm{~mm}$, and then they were carefully polished on $2000 \#$ abrasive paper before test. The $\mathrm{ZrO}_{2}$ ceramic was selected to be the yttrium stabilized zirconium dioxide (YSZ) with tetragonal structure. The physical and mechanical properties of the ceramic materials are shown in Table 1. The surface roughness $(\mathrm{Ra})$ of $1 \mathrm{Cr} 18 \mathrm{Ni}$ Ti stainless steel and $\mathrm{ZrO}_{2}, \mathrm{SiC}$, $\mathrm{Si}_{3} \mathrm{~N}_{4}$ ceramic discs were polished to $0.2 \sim 0.25 \mu \mathrm{m}$. The tests were carried out at an applied load of $35 \mathrm{~N}$, sliding speed of $300 \mathrm{r} / \mathrm{min}(0.690 \mathrm{~m} / \mathrm{s})$, and testing time of $30 \mathrm{~min}$.

The wear calculations of discs and pins were evaluated by wear volume and mass loss, respectively. The radius of the wear track was $22.5 \mathrm{~mm}$. As for the counterpart discs, the cross-section profile of worn surface was measured using white light confocal microscope (CM, Micromeasure2 STLE). The wear volume, $V=A L$, was defined as the cross-section area of wear track $(A)$ multiplied by the circumference of the worn track $(L)$. Four locations were measured in each wear track to determine $A$. With regards to the pins of the $1 \mathrm{Cr} 18 \mathrm{Ni}$ Ti steel, the mass before and after the test was both measured for calculating the wear loss. To make sure the reproducibility of the experimental results, all the tribological tests were carried out at least three times. Morphologies of the worn surfaces of the alloys and ceramics were analyzed by scanning electron

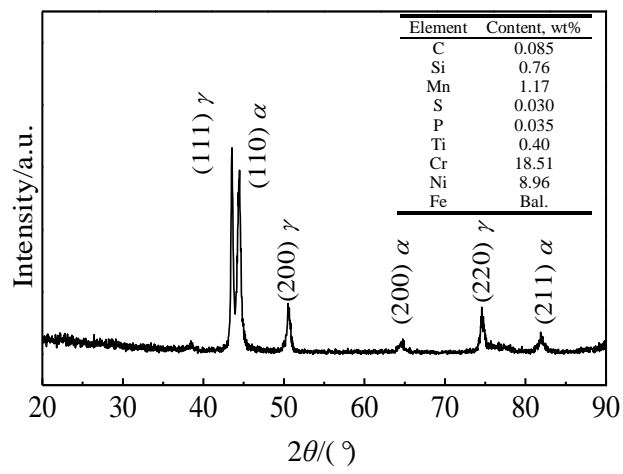

Fig.1 XRD pattern and chemical composition of 1Cr18Ni9Ti steel

Table 1 Physical and mechanical properties of the ceramic

\begin{tabular}{cccccc}
\hline Ceramic & $\begin{array}{c}\text { Density/ } \\
\mathrm{g} \cdot \mathrm{cm}^{-3}\end{array}$ & $\begin{array}{c}\text { Hardness, } \\
\mathrm{HR}_{45 \mathrm{~N}}\end{array}$ & $\begin{array}{c}\text { Young's } \\
\text { modulus } \\
/ \mathrm{GPa}\end{array}$ & $\begin{array}{c}\text { Fracture } \\
\text { toughness } \\
/ \mathrm{MPa} \cdot \mathrm{m}^{1 / 2}\end{array}$ & $\begin{array}{c}\text { Thermal } \\
\text { conductively/ } \\
\mathrm{W} \cdot(\mathrm{m} \cdot \mathrm{K})^{-1}\end{array}$ \\
\hline $\mathrm{ZrO}_{2}$ & 5.8 & 84 & 225 & 7.13 & 2.5 \\
$\mathrm{SiC}$ & 3.1 & 93 & 441 & 4.65 & 58.6 \\
$\mathrm{Si}_{3} \mathrm{~N}_{4}$ & 3.2 & 87 & 294 & 4.71 & 12.6 \\
\hline
\end{tabular}

microscopy (SEM JSM-6510LV) equipped with energy dispersive spectrometry (EDS).

\section{Results and Discussion}

Fig.2 shows the coefficient of friction (COF) curves of the $1 \mathrm{Cr} 18 \mathrm{Ni} 9 \mathrm{Ti}$ steel sliding against different counterparts at applied load of $35 \mathrm{~N}$ and sliding speed of $0.690 \mathrm{~m} / \mathrm{s}$ with sliding time of $30 \mathrm{~min}$. The COF of the $1 \mathrm{Cr} 18 \mathrm{Ni} 9 \mathrm{Ti}$ steel/ $/ \mathrm{ZrO}_{2}$ ceramic pair keeps the stabilization with about a high value fluctuating between 0.17 and 0.27 during the test process. For the $1 \mathrm{Cr} 18 \mathrm{Ni}$ Ti steel/SiC ceramic pair, the COF curve shows a gradual decreasing trend within $250 \mathrm{~s}$ at the initiatory stage, and then presents an excitingly low value of about 0.035 with the increase of time. In contrast to the smooth characteristics against $\mathrm{ZrO}_{2}$ and $\mathrm{SiC}$ ceramics, the $\mathrm{COF}$ curve of $1 \mathrm{Cr} 18 \mathrm{Ni} 9 \mathrm{Ti}$ steel rubbing against $\mathrm{Si}_{3} \mathrm{~N}_{4}$ ceramic is complex. In order to clearly describe the experimental results, the complex $\mathrm{COF}$ curve of $\mathrm{Si}_{3} \mathrm{~N}_{4}$ ceramic is decomposed into two regimes in the present work. $\alpha$ regime keeps the high value with distinct fluctuation similar to $\mathrm{ZrO}_{2}$ ceramic. $\beta$ regime is a complex process where the $\mathrm{COF}$ firstly decreases to the low value similar to SiC ceramic, and then increases sharply to the high value. In the COF curve of $1 \mathrm{Cr} 18 \mathrm{Ni} 9 \mathrm{Ti}$ steel/ $\mathrm{Si}_{3} \mathrm{~N}_{4}$ ceramic pair, $\alpha$ and $\beta$ regimes present alternately. With the continuation of sliding process, the duration of $\alpha$ regime decreases gradually. Namely, $\alpha$ regimes displayed in the test maintain at about 600, 400 and $50 \mathrm{~s}$, successively. The different friction behavior indicates that the counterpart plays an important role in the tribological behavior of $1 \mathrm{Cr} 18 \mathrm{Ni} 9 \mathrm{Ti}$ steel in $90 \%$ hydrogen peroxide solution.

Fig.3 illustrates the wear loss of the $1 \mathrm{Cr} 18 \mathrm{Ni} 9 \mathrm{Ti}$ steel pins and the wear volume of the three different ceramic discs. Both the wear loss of pin and the wear volume of disc in the $1 \mathrm{Cr} 18 \mathrm{Ni} 9 \mathrm{Ti}$ steel/ $\mathrm{ZrO}_{2}$ ceramic pair are obviously higher than those in other pairs. With low total wear loss, the tribo-pairs with $\mathrm{SiC}$ and $\mathrm{Si}_{3} \mathrm{~N}_{4}$ ceramics exhibit different wear properties of steel and ceramic. The wear loss of $1 \mathrm{Cr} 18 \mathrm{Ni} 9 \mathrm{Ti}$ steel rubbing against $\mathrm{SiC}$ ceramic, is the lowest, which is

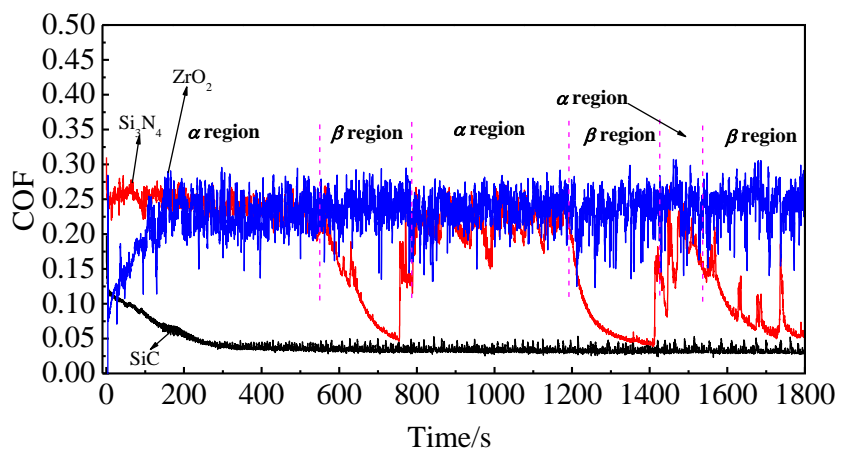

Fig.2 COF curves of the $1 \mathrm{Cr} 18 \mathrm{Ni} 9 \mathrm{Ti}$ steel sliding against $\mathrm{ZrO}_{2}$, $\mathrm{Si}_{3} \mathrm{~N}_{4}$ and $\mathrm{SiC}$ ceramics at $35 \mathrm{~N}$ and $0.690 \mathrm{~m} / \mathrm{s}$ with sliding time of $30 \mathrm{~min}$ 


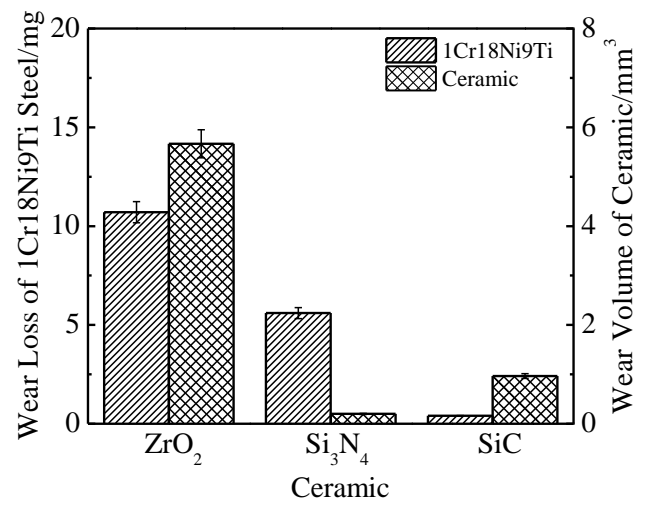

Fig.3 Wear loss of $1 \mathrm{Cr} 18 \mathrm{Ni}$ Ti steel pins, and wear volume of different ceramic discs

about one-fourteenth of that against $\mathrm{Si}_{3} \mathrm{~N}_{4}$ ceramic. With regard to the ceramics, the wear volume of $\mathrm{Si}_{3} \mathrm{~N}_{4}$ ceramic is the lowest, which is about 5 times lower than that of $\mathrm{SiC}$ ceramic. The mathematical relationship among the wear loss of $1 \mathrm{Cr} 18 \mathrm{Ni}$ Ti steel against different ceramics is $\mathrm{ZrO}_{2}(10.7$ $\mathrm{mg})>\mathrm{Si}_{3} \mathrm{~N}_{4}(5.6 \mathrm{mg})>\mathrm{SiC}(0.4 \mathrm{mg})$, and that among the wear volume of the ceramics is $\mathrm{ZrO}_{2}\left(5.67 \mathrm{~mm}^{3}\right)>\mathrm{SiC}(0.47$ $\left.\mathrm{mm}^{3}\right)>\mathrm{Si}_{3} \mathrm{~N}_{4}\left(0.21 \mathrm{~mm}^{3}\right)$.

Fig.4a and Fig.4b show the worn surfaces of $1 \mathrm{Cr} 18 \mathrm{Ni} 9 \mathrm{Ti}$ steel $/ \mathrm{ZrO}_{2}$ ceramic tribo-pair in $90 \%$ hydrogen peroxide solution. Rubbing with $\mathrm{ZrO}_{2}$ ceramic, the flaking-off behavior, parallel to the orientation of the sample sliding is displayed on the surface of $1 \mathrm{Cr} 18 \mathrm{Ni} 9 \mathrm{Ti}$ steel (in Fig.4a). EDS analysis taken from region $\mathrm{B}$ of $\mathrm{ZrO}_{2}$ ceramic (in Fig.4b) shows the signal of the $\mathrm{Fe}$ element, which indicates the transfer of $\mathrm{Fe}$ from $1 \mathrm{Cr} 18 \mathrm{Ni}$ Ti steel to the worn surface of $\mathrm{ZrO}_{2}$ ceramic during the sliding. The creation of chemical bonds among $\mathrm{Zr}$,
$\mathrm{O}$ and $\mathrm{Fe}$ elements leads to the adhesion behavior ${ }^{[12]}$. With the relatively low shearing strength, $1 \mathrm{Cr} 18 \mathrm{Ni} 9 \mathrm{Ti}$ steel is flaked-off and transformed onto the surface of $\mathrm{ZrO}_{2}$ ceramic by the relative movement. As for $\mathrm{ZrO}_{2}$ ceramic, besides the adhesion layer, fatigue cracks perpendicular to the sliding direction is observed in the Fig.5a. The repeated shearing and compressive stresses, caused by the rolling of detached adhesive particles between the contact surfaces ${ }^{[13]}$, results in the fatigue of $\mathrm{ZrO}_{2}$ ceramic.

The surface tracks for $1 \mathrm{Cr} 18 \mathrm{Ni} 9 \mathrm{Ti}$ steel and $\mathrm{Si}_{3} \mathrm{~N}_{4}$ ceramic after the tests are illustrated in Fig.4c and Fig.4d. The friction transfer is also observed between the contact surfaces of the $1 \mathrm{Cr} 18 \mathrm{Ni} 9 \mathrm{Ti}$ steel/ $\mathrm{Si}_{3} \mathrm{~N}_{4}$ ceramic. Obvious delamination behaviors are also presented on the surface of $1 \mathrm{Cr} 18 \mathrm{Ni} 9 \mathrm{Ti}$ steel in Fig.4c. The adhesion layers (region D) on the worn surface of $\mathrm{Si}_{3} \mathrm{~N}_{4}$ ceramic in Fig. $4 \mathrm{~d}$ are proved to contain $\mathrm{Fe}$ element by the EDS. A high chemical affinity exists between iron and $\mathrm{Si}_{3} \mathrm{~N}_{4}$ ceramic ${ }^{[14,15]}$ which is reasonable for forming of the adhesion behavior. Apart from the adhesion layers, it is noteworthy that the signal of the $\mathrm{O}$ element is observed on the no-adhesion region $\mathrm{E}$ of $\mathrm{Si}_{3} \mathrm{~N}_{4}$ ceramic. S. F. Ren et al. and $\mathrm{J}$. $\mathrm{Xu}$ el al. reported that $\mathrm{Si}_{3} \mathrm{~N}_{4}$ ceramic should be tribo-oxidated in oxidizing medium when accelerated by friction ${ }^{[16,17]}$. The oxidation and hydrolysis reactions, as represented in Eq.(1) and Eq. $(2)^{[11]}$, could occur on the worn surface of $\mathrm{Si}_{3} \mathrm{~N}_{4}$ ceramic when friction takes place in hydrogen peroxide solution. The formed colloidal film of $\mathrm{SiO}_{2} \cdot n \mathrm{H}_{2} \mathrm{O}$ and $\mathrm{Si}(\mathrm{OH})_{4}$ could reduce the friction and wear loss. In $90 \%$ hydrogen peroxide solution, the wear mechanism of the $1 \mathrm{Cr} 18 \mathrm{Ni9Ti}$ steel/ $\mathrm{Si}_{3} \mathrm{~N}_{4}$ ceramic rubbing pair, is affected by both adhesion behavior and the protective film formed by oxidation and hydrolysis reactions.
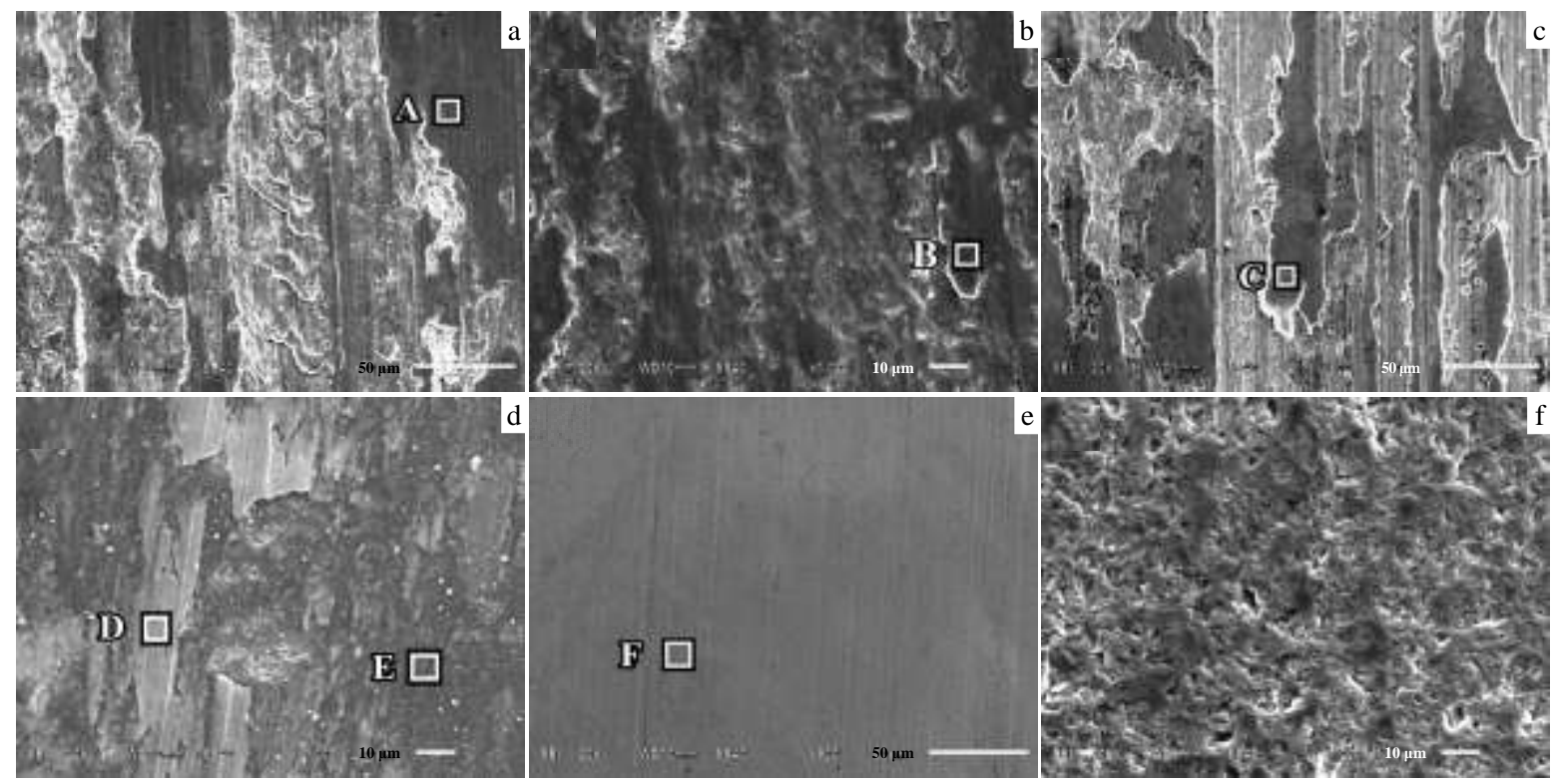

Fig.4 SEM images of the $1 \mathrm{Cr} 18 \mathrm{Ni}$ TTi steels and different counterparts after wear test: (a, b) $1 \mathrm{Cr} 18 \mathrm{Ni} 9 \mathrm{Ti}$ steel/ZrO ${ }_{2}$ ceramic, (c, d) $1 \mathrm{Cr} 18 \mathrm{Ni} 9 \mathrm{Ti}$ steel/ $\mathrm{Si}_{3} \mathrm{~N}_{4}$ ceramic, and (e, f) $1 \mathrm{Cr} 18 \mathrm{Ni} 9 \mathrm{Ti}$ steel/ $\mathrm{SiC}$ ceramic 
$\mathrm{Si}_{3} \mathrm{~N}_{4}+6 \mathrm{H}_{2} \mathrm{O} \rightarrow 3 \mathrm{SiO}_{2}+4 \mathrm{NH}_{3}$

$$
\mathrm{SiO}_{2}+(n+2) \mathrm{H}_{2} \mathrm{O} \rightarrow \mathrm{SiO}_{2} \cdot n \mathrm{H}_{2} \mathrm{O}+\mathrm{Si}(\mathrm{OH})_{4}
$$

Fig.4e and Fig.4f show the morphological characteristics of the $1 \mathrm{Cr} 18 \mathrm{Ni}$ Ti steel/SiC ceramic tribo-pair after test in $90 \%$ hydrogen peroxide solution. In contrast to the rough worn tracks against $\mathrm{ZrO}_{2}$ and $\mathrm{Si}_{3} \mathrm{~N}_{4}$ ceramic, the worn surface of $1 \mathrm{Cr} 18 \mathrm{Ni}$ Ti steel against $\mathrm{SiC}$ ceramic (in Fig.4e) is very smooth. There are no delamination and adhesion characteristics, only shallow abrasive grooves along the sliding direction observed on the surface of $1 \mathrm{Cr} 18 \mathrm{Ni}$ Ti steel. With regard to $\mathrm{SiC}$ ceramic, the characteristic of dispersive pits are presented on the worn surface in Fig.4f. Details reveal that cracks are formed on the surface of $\mathrm{SiC}$ ceramic in Fig.5b, and the compositions of different regions such as region $\mathrm{G}$ and region $\mathrm{H}$ are shown in Table 2. The initiation and the propagation of the cracks during the wear process lead to the formation of pits. By comparing the surfaces of $1 \mathrm{Cr} 18 \mathrm{Ni} 9 \mathrm{Ti}$ steel before and after wear in Fig.6, it is found that wear process of $1 \mathrm{Cr} 18 \mathrm{Ni} 9 \mathrm{Ti}$ steel/SiC ceramic actually creates a polishing action on the surface of $1 \mathrm{Cr} 18 \mathrm{Ni}$ TTi steel. K. Yagi et $a l$. and A. Kubota el al. reported that $\mathrm{OH}$ radicals $(\mathrm{OH} \cdot)$ could be obtained from the reaction of $\mathrm{H}_{2} \mathrm{O}_{2}$ molecules with the iron. The formed $\mathrm{OH}$ - could break the $\mathrm{Si}-\mathrm{C}$ bonds during tribochemical reaction. When attacked by $\mathrm{OH} \cdot$, the surface of $\mathrm{SiC}$ was oxidized and hydrolyzed as Eq.(3) and Eq.(2) ${ }^{[18,19]}$. Rubbing with the iron-based $1 \mathrm{Cr} 18 \mathrm{Ni}$ Ti steel, SiC ceramic reacts seriously with the hydrogen peroxide solution. The producing of $\mathrm{SiO}_{2}$ creates polishing action, and the existence of colloidal film could protect the surfaces of SiC ceramic and $1 \mathrm{Cr} 18 \mathrm{Ni} 9 \mathrm{Ti}$ steel contacting. Under the synergy of $\mathrm{SiO}_{2}$, colloidal film, the $1 \mathrm{Cr} 18 \mathrm{Ni} 9 \mathrm{Ti}$ steel is polished during the wear process.

$$
\mathrm{SiC}+4 \mathrm{OH} \cdot+\mathrm{O}_{2} \rightarrow \mathrm{SiO}_{2}+2 \mathrm{H}_{2} \mathrm{O}+\mathrm{CO}_{2}
$$

According to the above discussions, the wear mechanisms of $1 \mathrm{Cr} 18 \mathrm{Ni} 9 \mathrm{Ti}$ steel/ $\mathrm{ZrO}_{2}$ ceramic and $1 \mathrm{Cr} 18 \mathrm{Ni} 9 \mathrm{Ti}$ steel/SiC ceramic pairs are mainly affected by the adhesion behavior, the reactions of oxidation and hydrolysis, respectively. Both the adhesion behavior and the reactions, play important roles in the wear process of $1 \mathrm{Cr} 18 \mathrm{Ni} 9 \mathrm{Ti}$ steel $/ \mathrm{Si}_{3} \mathrm{~N}_{4}$ ceramic (in Fig.7). Therefore, rubbing against $\mathrm{ZrO}_{2}$ ceramic, the flakingoff behavior caused by adhesion, leads to the highest wear loss of $1 \mathrm{Cr} 18 \mathrm{Ni} 9 \mathrm{Ti}$ steel. The $\mathrm{SiO}_{2}$ and colloidal film produced between the $1 \mathrm{Cr} 18 \mathrm{Ni}$ Ti steel and $\mathrm{SiC}$ ceramic reduce the attrition, and lead to the lowest wear loss of $1 \mathrm{Cr} 18 \mathrm{Ni}$ Ti steel. The wear loss of $1 \mathrm{Cr} 18 \mathrm{Ni} 9 \mathrm{Ti}$ steel against $\mathrm{Si}_{3} \mathrm{~N}_{4}$ ceramic is intermediate, due to both the delamination caused by adhesion and the protective film. As for the ceramics, the subsequent propagation of the cracks leads to a high wear volume of $\mathrm{ZrO}_{2}$

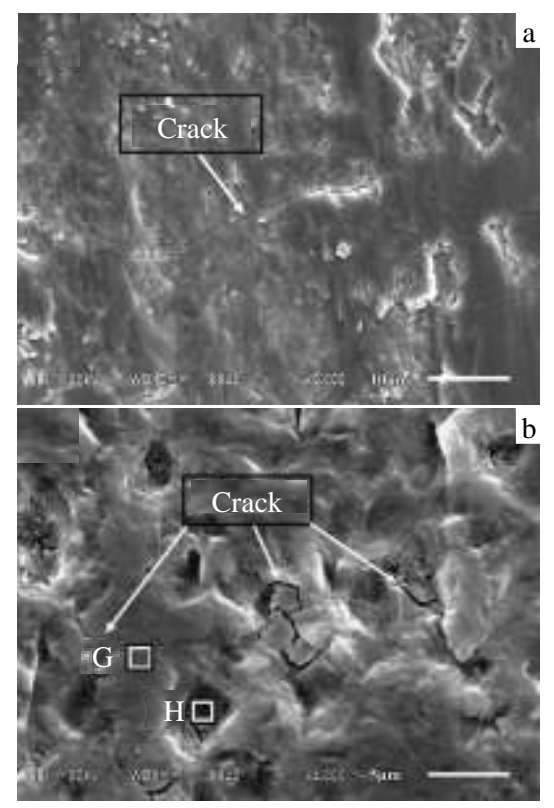

Fig.5 High magnification of the worn surface of $\mathrm{ZrO}_{2}$ ceramic (a) and $\mathrm{SiC}$ ceramic (b)

Table 2 EDS analysis corresponding to the worn surfaces of the $1 \mathrm{Cr} 18 \mathrm{Ni9Ti}$ steels and different counterparts in Fig.4 and Fig.5 (at\%)

\begin{tabular}{ccccccccccc}
\hline Region & $\mathrm{Fe}$ & $\mathrm{Mn}$ & $\mathrm{Cr}$ & $\mathrm{Ni}$ & $\mathrm{Ti}$ & $\mathrm{Zr}$ & $\mathrm{Si}$ & $\mathrm{C}$ & $\mathrm{O}$ & $\mathrm{N}$ \\
\hline $\mathrm{A}$ & 50.1 & 0.7 & 13.8 & 6.0 & & 2.1 & 1.8 & & 25.6 & \\
$\mathrm{~B}$ & 19.8 & & 4.6 & 1.8 & & 12.6 & & & 61.2 & \\
$\mathrm{C}$ & 59.8 & 1.2 & 16.5 & 6.6 & 0.4 & & 2.2 & & 13.4 & \\
$\mathrm{D}$ & 32.7 & & 7.7 & 3.9 & & & 27.5 & & 28.2 & \\
$\mathrm{E}$ & 0.3 & & & & & & 49.2 & & 16.1 & 34.4 \\
$\mathrm{~F}$ & 64.3 & 1.2 & 18.2 & 7.3 & & & 2.1 & 0.1 & 6.3 & \\
$\mathrm{G}$ & & & & & & & 81.6 & 10.0 & 8.4 & \\
$\mathrm{H}$ & 3.2 & & & & & & 64.6 & 7.5 & 24.7 & \\
\hline
\end{tabular}

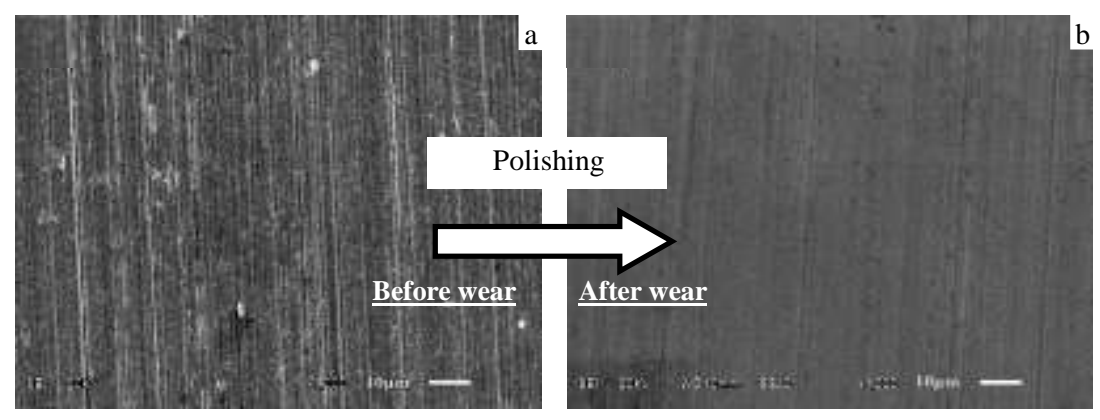

Fig.6 SEM images of the surface of 1Cr18Ni9Ti steel rubbing with SiC ceramic: (a) before wear and (b) after wear 


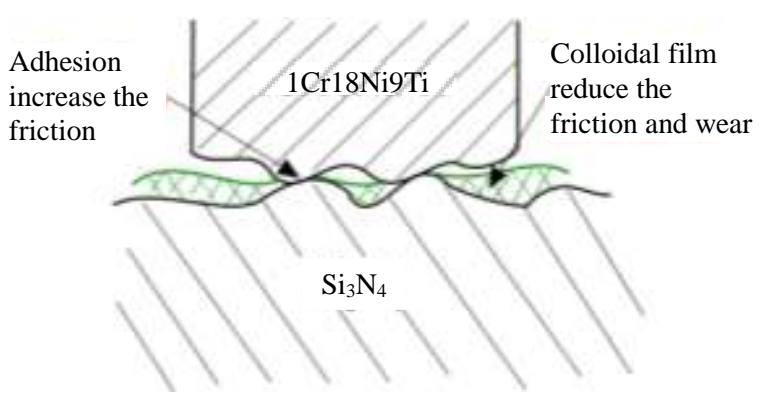

Fig.7 Wear mechanism of $1 \mathrm{Cr} 18 \mathrm{Ni} 9 \mathrm{Ti}$ steel/ $\mathrm{Si}_{3} \mathrm{~N}_{4}$ pair in $90 \%$ $\mathrm{H}_{2} \mathrm{O}_{2}$ solution

ceramic. The wear volume of $\mathrm{SiC}$ ceramic with the produced pits is higher than that of $\mathrm{Si}_{3} \mathrm{~N}_{4}$ ceramic sticking with 1Cr18Ni9Ti steel.

The junctions, which are the key of the adhesion process and sheared under the applied tangential force result in the frictional force. The formation and the rupture of the junctions control the adhesion component of friction ${ }^{[20]}$. As a result, coupled with $\mathrm{ZrO}_{2}$ ceramic, the COF keeps a high value with a distinct fluctuation. With regard to the $1 \mathrm{Cr} 18 \mathrm{Ni} 9 \mathrm{Ti}$ steel/SiC ceramic pair, the producing of $\mathrm{SiO}_{2}$ creates polishing action, and the existence of $\mathrm{SiO}_{2} \cdot n \mathrm{H}_{2} \mathrm{O}$ and $\mathrm{Si}(\mathrm{OH})_{4}$ results in the formation a colloidal film to reduce the friction coefficient. Rubbing with $\mathrm{SiC}$ ceramic, the COF keeps an excitingly low value with very slight fluctuation. The friction behavior of the $1 \mathrm{Cr} 18 \mathrm{Ni} 9 \mathrm{Ti}$ steel/ $\mathrm{Si}_{3} \mathrm{~N}_{4}$ ceramic is complex. The work of $\mathrm{X}$. Z . Zhao et al. proved that the adhesion behavior between $1 \mathrm{Cr} 18 \mathrm{Ni}$ Ti steel and $\mathrm{Si}_{3} \mathrm{~N}_{4}$ ceramic could lead to severe friction ${ }^{[21]}$. At the beginning, the direct contact between the pair causes serious adhesion, inducing the COF with a high value and a distinct fluctuation. With the sliding process, the colloidal film is formed due to the oxidation and hydrolysis reaction. When the colloidal film is integrated enough, the COF decreases to the value similar to that against $\mathrm{SiC}$ ceramic. However, as the colloidal film is not compact enough and the adhesion surface is rough, the colloidal film is easily ruptured. The adhesion behavior occurs again, leading to the COF turning high. These two mechanisms appear alternately. By the reason that the oxidation and hydrolysis reaction keeps occurring in the hydrogen peroxide solution, the colloidal film becomes more and more integrated, homogeneous and compact with the increase of wear time. Thus, the duration of $\alpha$ regime with the high COF which is caused by the adhesion shows a trend of decrease.

\section{Conclusions}

1) Adhesion behavior occurs between $1 \mathrm{Cr} 18 \mathrm{Ni} 9 \mathrm{Ti}$ steel $/ \mathrm{ZrO}_{2}$ ceramic pair, leading to the high $\mathrm{COF}$ with a distinct fluctuation. Due to the flaking-off behavior by adhesion, $1 \mathrm{Cr} 18 \mathrm{Ni}$ TTi steel against $\mathrm{ZrO}_{2}$ ceramic exhibits the highest wear loss.

2) The $\mathrm{SiO}_{2}$ and colloidal film, produced by the oxidation and hydrolysis reactions of $\mathrm{SiC}$ ceramic in the hydrogen peroxide solution, protect the worn surface, resulting in the low $\mathrm{COF}$ of $1 \mathrm{Cr} 18 \mathrm{Ni} 9 \mathrm{Ti}$ steel/SiC ceramic pair and the lowest wear loss of $1 \mathrm{Cr} 18 \mathrm{Ni}$ Ti steel. The wear process against $\mathrm{SiC}$ ceramic creates a polishing action on the surface of 1Cr18Ni9Ti steel.

3) The wear mechanism of $1 \mathrm{Cr} 18 \mathrm{Ni} 9 \mathrm{Ti}$ steel/ $/ \mathrm{Si}_{3} \mathrm{~N}_{4}$ ceramic pair is affected by both adhesion behavior and hydrolysis reactions. The COF curve contains two alternate regimes, and the wear loss of $1 \mathrm{Cr} 18 \mathrm{Ni}$ Ti steel show an intermediate loss.

\section{References}

1 Ventura M, Mullens P. Proceedings of the 35th AIAA/ASME/ SAE/ASEE Joint Propulsion Conference and Exhibit [C]. Los Angeles, American: Institute of Aeronautics and Astronautics, 1999

2 Gostowski R. Thermochim Acta[J], 2003, 404: 279

3 Yuan C Q, Li J, Dong C L et al. Wear[J], 2011, 271: 1617

4 Constantine M T, Cain E F C. Hydrogen Peroxide Handbook[M]. Canada: AFRPL, 1967: 165

5 Li Y, Hu R, Wang J et al. Electrochim Acta[J], 2009, 54: 7134

6 Dong L L. Journal of Rocket Propulsion[J], 2004, 30: 32 (in Chinese)

7 Yao Xiaofei, Xie Faqin, Han Yong et al. Rare Metal Materials and Engineering[J], 2012, 41(9): 1539 (in Chinese)

8 Li Yongquan, Xie Faqin, Wu Xiangqing et al. Rare Metal Materials and Engineering[J], 2013, 42(11): 2257 (in Chinese)

9 Yu Y, Liu W M, Zhang T B et al. Metall Mater Trans A[J], 2014, 45(1): 201

10 Hu Rui, Yuan Qinlu, Li Jinshan et al. Rare Metal Materials and Engineering[J], 2005, 34 (4): 653 (in Chinese)

11 Duan H T, Wu Y, Hua M et al. Wear[J], 2013, 297: 1045

12 Hiasuyama H, Shima Y, Baba K et al. Nucl Instrum Meth B[J], 1997, 127-128: 827

13 Souza R C, Santos C D, Barboza M J R et al. J Mater Res Technol[J], 2014, 3(1): 48

14 Zhao X Z, Liu J J, Zhu B L et al. J Mater Eng Perform[J], 1997, 6: 203

15 Tong Y X, Wang L Q, Gu L. Adv Mater Res[J], 2010, 1681: 97

16 Ren S F, Lu J J, Jia Q Z et al. Tribol Int[J], 2014, 74: 174

17 Xu J, Kato K. Wear[J], 2000, 245: 61

18 Yagi K, Murata J, Kubota A et al. Surf Interface Anal[J], 2008, 40: 998

19 Kubota A, Yoshimura M, Fukuyama S et al. Precis Eng[J], 2012, 36: 137

20 Myshkin N K, Petrokovets M I, Kovalev A V. Tribol Int [J], 2005, 38: 910

21 Zhao X Z, Liu J J, Zhu B L et al. The 6th China Tribology Conference[C]. Xi'an: Xi'an Jiaotong University, 1997 (in Chinese) 


\title{
过氧化氢环境下 $1 \mathrm{Cr} 18 \mathrm{Ni9Ti}$ 不锈钢与不同陶瓷配副的摩擦学行为
}

\author{
于 源 $^{1}$, 王 军 ${ }^{1}$, 李金山 ${ }^{1}$, 寇宏超 ${ }^{1}$, 段海涛 ${ }^{2}$, 李 健 $^{2}$, 刘维民 ${ }^{3}$
}

(1. 西北工业大学 凝固技术国家重点实验室, 陕西 西安 710072)

(2. 武汉材料保护研究所, 湖北 武汉 430000)

(3. 中国科学院兰州化学物理研究所 固体润滑国家重点实验室, 甘肃 兰州 730000)

\begin{abstract}
摘 要: 研究了 $\mathrm{ZrO}_{2}, \mathrm{Si}_{3} \mathrm{~N}_{4}$ 和 $\mathrm{SiC} 3$ 种陶瓷配副对 $1 \mathrm{Cr} 18 \mathrm{Ni} 9 \mathrm{Ti}$ 不锈钢在 $90 \%$ 的 $\mathrm{H}_{2} \mathrm{O}_{2}$ 溶液中摩擦学性能的影响。结果表明, $1 \mathrm{Cr} 18 \mathrm{Ni} 9 \mathrm{Ti}$ 不锈钢在该环境下的摩擦学性能受配副的影响明显。与 $\mathrm{ZrO}_{2}$ 对磨, 发生了粘着行为, 导致了大的摩擦系数 (0.17 0.27) 和最高的 $1 \mathrm{Cr} 18 \mathrm{Ni} 9 \mathrm{Ti}$ 不锈钢磨损量。与 $\mathrm{SiC}$ 对磨, 发生了氧化和水解反应, 形成的胶体膜起到了润滑作用, 导致了小的摩擦系数 (0.035) 和最 低的 $1 \mathrm{Cr} 18 \mathrm{Ni}$ i Ti 不锈钢磨损量。粘着行为和水解反应均发生于 $1 \mathrm{Cr} 18 \mathrm{Ni} 9 \mathrm{Ti} / \mathrm{Si}_{3} \mathrm{~N}_{4}$ 的磨损过程中, 粘着与保护膜的耦合, 导致了复杂的摩 擦系数。对于配副, $\mathrm{ZrO}_{2}$ 的磨损体积最大, $\mathrm{SiC}$ 最小, $\mathrm{Si}_{3} \mathrm{~N}_{4}$ 表面有粘着层, 因此磨损体积介于上述 2 种陶瓷之间。

关键词: 过氧化氢; 摩擦学性能; 配副; 摩擦化学; 粘着
\end{abstract}

作者简介: 于 源, 男, 1987 年生, 博士生, 西北工业大学凝固技术国家重点实验室, 陕西 西安 710072, 电话: 029-88491764, E-mail: yuyuannpu@163.com 